\title{
Editorials
}

\section{2th World Congress of Anaesthesiologists}

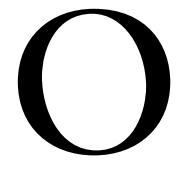

$\mathrm{N}$ June 4th 2000, the 12th World Congress of Anaesthesiologists will open in Montreal. For the second time in its history, the Canadian Anesthesiologists' Society will host this world meeting. What is the World Congress of Anaesthesiologists and what are its origins?

The World Federation of Societies of Anaesthesiologists (WFSA) was founded in 1955, with Harold Griffith of Montreal elected its first President. The groundwork for this new organisation was laid over many years. Leaders from both sides of the Atlantic felt a need for a forum where anesthesiologists from all over the world could get together to exchange ideas. At that time anesthesiologists, and their organisations, were just beginning to emerge from the control of surgeons. The International Anesthesia Research Society, based in the United States but with Harold Griffith at its head, provided financial and moral support for the development of the new organisation. In 1951 a committee was set up to explore the possibilities and, at a meeting in Brussels in June 1953, it was agreed to establish the WFSA.

Many famous names in anesthesia were associated with this development; Griffith, John Gillies, Torsten Gordh, Wesley Bourne, Geoffrey Organe and Harry Seldon to name a few. The first congress of the fledgling organisation was held in Scheveningen, The Netherlands, from September 5-10, 1955. Since the 2nd congress in Toronto, meetings have been held every four years at venues throughout the world.

To be considered as a host for a World Congress, a national society must enter a bid and compete against other societies bidding for the same congress. An international committee of the WFSA determines the winner. In 1988, in Washington DC, a Canadian team led by Gordon Sellery and Jean Taillefer, bid for and won the 12th World Congress for Canada. Serious work in preparation for the congress began in 1995.

What distinguishes a World Congress from other events? It is truly world in scope. In Montreal, there will be delegates from 118 countries. There will be over 500 speakers representing 55 countries. There will be supported Fellows from 45 countries. No other meeting is so widely representative. No other meeting has so many diverse topics for discussion. At no other meeting can you meet your colleagues from Albania to Zimbabwe. In addition to this, all speakers support their own trav$\mathrm{el}$, accommodation and registration expenses in order to keep costs as low as possible.

What were the aims of the founders of the WFSA and how have they succeeded? The main purpose of the WFSA, as stated in the constitution, is "to make available better anaesthesia to more people throughout the world". In pursuit of this objective, the WFSA aims:

1. To assist and encourage the formation of national societies of anesthesiologists.

2. To promote the dissemination of scientific information.

3. To recommend desirable standards of training for anesthesiologists.

4. To provide information regarding opportunities for postgraduate training and research.

5. To encourage research into all aspects of anesthesiology.

6. To encourage the establishment of safety measures including standardization of equipment.

7. To advise, upon request, national and international organizations.

The WFSA now has 103 member societies and eight more awaiting approval. The World Congress serves as a major forum for the dissemination of scientific information. The WFSA publishes World Anaesthesia Newsletter and Update in Anaesthesia. Both are widely distributed and are available on the Internet. Educational materials such as textbooks and videos are sent to teaching centres throughout the world. Ninety two centres have benefitted since the service began five years ago.

To fulfill its educational mandate, the WFSA has helped establish advanced training centres where

Address correspondence to: Angela Enright MB FRCPC, President, $12^{\text {th }}$ World Congress of Anaesthesiologists

Victoria, B.C. E-mail: ape@telus.net

CAN J ANESTH 2000/47: $6 /$ pp 483-485 
young anesthesiologists can further their training without having to leave their own country. Last year, 25 refresher courses were held and 15 visiting professors were funded. New initiatives have been taking place in the Pacific Islands, Thailand, Nigeria, Nepal, Uganda and India. The Education Committee of the WFSA fosters cooperation between affluent and developing nations.

The area of safety is developing under the guidance of the Committee on Quality of Practice and equipment, technology and standards are under discussion by the Technology Committee. The WFSA maintains strong links to the World Health Organisation. Thus it appears that most of the ideals and aims of Griffith and his colleagues are being fulfilled.

And so to Montreal: what can you expect? There will be a scientific programme second to none, with variety and choice of amazing proportions. The social programme will whirl on all week from the formal opening ceremonies on Sunday, through figure-skating, the opera, the symphony and a visit to Nouvelle France, to the final curtain on Friday. Old friendships will be renewed. New links will be forged. This will be an unforgettable week.

\section{Le 12. Congrès mondial des anesthésiologistes}

Le 4 juin 2000 s'ouvrira à Montréal le $12^{\text {e }}$ Congrès mondial des anesthésiologistes. Pour la seconde fois de son histoire, la Société canadienne des anesthésiologistes sera l'hôte de cette conférence mondiale. Qu'est-ce que le Congrès mondial des anesthésiologistes et quelle en est l'origine ?

La World Federation of Societies of Anaesthesiologists (WFSA), c'est-à-dire la Fédération mondiale des Sociétés d'anesthésiologistes, a été fondée en 1955 et c'est Harold Griffith de Montréal qui a été élu comme premier président. Il a fallu de nombreuses années pour jeter les bases de cette nouvelle organisation. Des sommités des deux côtés de l'Atlantique sentaient le besoin d'un forum où les anesthésiologistes du monde entier pourraient se rencontrer et échanger des idées. À cette époque, les anesthésiologistes et leurs organisations commençaient à peine à s'affranchir du contrôle des chirurgiens. L'International Anesthesia Research Society, ou Société internationale de recherche en anesthésie, basée aux États-Unis mais dirigée par Harold Griffith, a fourni un soutien financier et moral pour le développement de la nouvelle organisation. En 1951, un comité a été mis sur pied pour explorer les possibilités d'une fédération et, lors d'une rencontre à Bruxelles en juin 1953, on s'est entendu pour fonder la WFSA.

De nombreuses personnalités en anesthésie ont été associées à ce développement; Griffith, John Gillies, Torsten Gordh, Wesley Bourne, Geoffrey Organe et Harry Seldon pour n'en nommer que quelques-uns. Le premier congrès de la jeune organisation a été tenu à Scheveningen, aux Pays-Bas, du 5 au 10 septembre 1955. Depuis le $2^{\mathrm{c}}$ congrès à Toronto, des réunions ont eu lieu tous les quatre ans un peu partout dans le monde.

Pour devenir l'hôte d'un Congrès mondial, une société nationale doit faire une demande et concurrencer d'autres sociétés qui ont fait de même. Un comité international de la WFSA détermine le gagnant. En 1988, à Washington DC, une équipe canadienne dirigée par Gordon Sellery et Jean Taillefer, a présenté une demande et a été choisie pour organiser le $12^{\mathrm{e}}$ Congrès mondial au Canada. Un important travail de préparation a commencé en 1995.

Qu'est-ce qui distingue un Congrès mondial d'autres événements ? C'est certainement son envergure mondiale. À Montréal, il y aura des délégués de 112 pays. Plus de 500 conférenciers représenteront 55 pays. Des «Fellows» subventionnés proviendront de 45 pays. Aucune autre rencontre n'est aussi largement représentative. Aucune autre réunion n'a autant de sujets de discussion différents. Aucune autre ne vous permettra de rencontrer vos collègues d'Albanie au Zimbabwe. De plus, tous les conférenciers assument le coût de leurs déplacement, hébergement et droits d'inscription afin de maintenir les frais de congrès les plus bas possibles.

Quels étaient les buts des fondateurs de la WFSA et comment les ont-ils atteints ? L'objectif principal de la WFSA, comme l'indique sa constitution, est de «d'offrir une meilleure anesthésie à plus de gens dans le monde». Dans ce but, la WFSA vise à :

1. Aider et encourager la formation de sociétés nationales d'anesthésiologistes.

2. Promouvoir la diffusion de l'information scientifique.

3. Recommander des normes souhaitables de formation pour les anesthésiologistes.

4. Fournir de l'information concernant les possibilités de formation spécialisée et de recherche.

5. Encourager la recherche pour tous les aspects de l'anesthésiologie.

6. Favoriser l'établissement de mesures de sécurité, y compris la normalisation du matériel. 
7. Conseiller, sur demande, les organisations nationales et internationales.

La WFSA compte maintenant 103 sociétés membres et huit sont en attente d'un agrément. Le Congrès mondial sert de forum principal pour la diffusion d'information scientifique. La WFSA publie la World Anaesthesia Newsletter and Update in Anaesthesia (Bulletin mondial d'information en anesthésie et Mise à jour en anesthésie). Les deux publications sont largement distribuées et sont offertes sur Internet. Du matériel pédagogique comme des manuels et des vidéos sont envoyés à des centres de formation à travers le monde. Quatre-vingt-douze centres en ont bénéficié depuis l'ouverture du service il y a cinq ans.

Afin de remplir son mandat éducatif, la WFSA a aidé à établir des centres de formation avancée où de jeunes anesthésiologistes peuvent perfectionner leur savoir sans devoir quitter leur propre pays. L'an dernier, 25 mises à jour ont été présentées et 15 professeurs invités ont été subventionnés. De nouvelles initiatives ont été mises en place dans les îles du Pacifique, en Thaïlande, au Nigéria, au Népal, en Ouganda et en Inde. Le Comité d'éducation de la WFSA encourage la coopération entre les pays riches et pauvres.

Le domaine de la sécurité se développe sous la surveillance du Comité sur la qualité de la pratique (Committee on Quality of Practice), et le matériel, la technologie et les normes sont étudiés par le Comité de technologie (Technology Committee). La WFSA maintient des liens étroits avec l'Organisation mondiale de la Santé. Il semble donc que la plupart des idéaux et des objectifs de Griffith et de ses collègues sont devenus réalité.

Quant à Montréal : à quoi peut-on s'attendre ? Il y aura le meilleur programme scientifique possible avec une diversité et un choix étonnants. Le programme des activités sociales sera en marche toute la semaine, des cérémonies officielles d'ouverture du congrès le dimanche, en passant par le patinage artistique, l'opéra, la musique symphonique et une visite en Nouvelle-France, jusqu'à la clôture le vendredi. De vieilles amitiés vont se renouer. De nouveaux liens vont se créer. Ce sera une semaine inoubliable. 